\title{
The care by obstetric nurses: the encounter between self care bodies and other woman who is cared for
}

O cuidado para enfermeiras obstétricas: encontro entre o corpo de si e da mulher cuidada El cuidado para enfermeras obstétricas: el encuentro entre su cuerpo y el de la mujer atendida

\author{
Ana Renata Moura Rabelo ${ }^{1}$ (i⿱ \\ Elysângela Dittz Duarte ${ }^{1}$ \\ Bruna Dias França ${ }^{1}$ \\ Kênia Lara Silva ${ }^{1}[0$
}

1. Universidade Federal de Minas Gerais, Escola de Enfermagem. Belo Horizonte, MG, Brasil.
Corresponding author:

Ana Renata Moura Rabelo

E-mail: anarmrabelo@gmail.com

Submitted on 05/02/2019.

Accepted on 10/16/2019.

DOI: 10.1590/2177-9465-EAN-2019-0131

\begin{abstract}
Objective: To analyze the obstetric nurses' discourse on self-care and decisions make of their life and body, and their relation with care for other women. Method: A qualitative, post-structuralist research with 14 obstetric nurses. Data were obtained from in-depth interviews and submitted to discourse analysis, based on the concepts of Foucault. Results: The findings reveal that caring of obstetric nurses is produced in the encounter between their own body and the body of the women under their care. The nursing profession was presented not only as a means of work and support but as an essential device for the training of women as subjects. The collective narrative is marked by the attitude of compassion, by the processes of subjectivity incited by the professional practice, by indicators of critical and political care, and by the construction of an interlocking network among obstetrical nurses. Conclusions and implications for practice: Acting in obstetric nursing results in self-care and care(less) effects of other women. The study contributes to the analysis and knowledge of the life and work scenario of obstetrical nurses It also reassures the potential of care as an art that is present in the women's practices.
\end{abstract}

Keywords: Obstetric Nursing. Feminism; Humanizing Delivery; Women's Health.

\section{Resumo}

Objetivo: Analisar os discursos de enfermeiras obstétricas sobre o cuidado de si e as decisões sobre sua vida e seu corpo, bem como a relação com o cuidado destinado a outras mulheres. Metódo: Pesquisa qualitativa, de referencial pós-estruturalista. Dados obtidos de entrevistas em profundidade com 14 enfermeiras obstétricas e submetidos à analítica do discurso, tendo como base conceitual Foucault. Resultados: Os achados revelam que o cuidado para a enfermeira obstétrica é produzido no encontro entre o corpo de si e o corpo das mulheres sob cuidados. A profissão de enfermagem apresentou-se não apenas enquanto meio de trabalho e sustento, mas como importante dispositivo para formação das mulheres enquanto sujeitos. A narrativa coletiva é marcada pela atitude de compaixão, por processos de subjetivação incitados pela prática profissional, por indicativos de um cuidado crítico e político, e pela construção de uma rede de imbricamento entre as enfermeiras obstétricas Conclusões e implicações para a prática: A atuação em enfermagem obstétrica resulta em efeitos produtores de cuidado de si e de (des)cuidado de outras mulheres. $O$ estudo contribui para a análise e o conhecimento do cenário de vida e de trabalho das enfermeiras obstétricas e a reafirmação do potencial de cuidado presente nas práticas destas mulheres.

Palavras-chave: Enfermagem obstétrica; Feminismo; Parto Humanizado; Saúde da Mulher.

\section{REsumen}

Objetivo: Analizar los discursos de enfermeras obstétricas sobre su propio cuidado y las decisiones sobre su vida y cuerpo, asi como la relación con el cuidado de otras mujeres. Metodo: Investigación cualitativa, desde una perspectiva postestructuralista Los datos se obtuvieron a partir de entrevistas en profundidad con 14 enfermeras obstétricas y se los sometió al análisis de discurso, basado en el concepto de Foucault. Resultados: Los hallazgos revelan que el cuidado para la enfermera obstétrica se produce en el encuentro entre su propio cuerpo y el de las mujeres a las que atiende. La profesión de enfermería se presentó no solo como un medio de trabajo y apoyo financiero, sino como un dispositivo para la formación de mujeres como sujetos. La narrativa colectiva está marcada por la actitud de compasión, por los procesos de subjetivación incitados por la práctica profesional, por indicativos de atención crítica y política, y por la construcción de una red de entrelazamiento entre enfermeras obstétricas. Conclusiones e implicaciones para la práctica: Desempeñarse como enfermera obstétrica deriva en efectos que producen el cuidado propio y el de otras mujeres. El estudio contribuye al análisis y conocimiento del escenario de vida y trabajo de las enfermeras obstétricas y a la reafirmación del potencial de cuidado presente en las prácticas de estas mujeres.

Palabras clave: Enfermeria Obstétrica; Feminismo; Parto Humanizado; Salud de la mujer. 


\section{INTRODUCTION}

Women live in a scenario permeated by advances and challenges, whether in the professional or in the family aspects and, properly, of the social relations. As a result of daily struggles, especially of the feminist movements, there were several achievements such as access to oral contraception and the entry of women to the labor market. ${ }^{1}$ On the other hand, there is a reality in which women are "thrown into exclusion by a prejudiced, patriarchal, unjust and inhuman social and economic model", 2:5 with increasing rates of violence in the various areas of life. This reality is related to an inter-sectional perspective of the classification systems based on social markers of difference, i.e., it considers not only gender hegemony, but also other markers that shape the production of subjectivities such as class, race/ skin color, sexual orientation, age/generation. ${ }^{3}$

The reality of the health services and of the practices of the health professionals directed at women is also marked by advances and challenges. The persistence is highlighted of high maternal mortality ratios, high caesarean section rates and the volume of unnecessary interventions, disciplinary and normative actions of women's behavior, with an approach based on gender a key device for addressing the different vulnerabilities to which they are subjected. ${ }^{2,4}$ Specifically in the childbirth care scenario in Brazil, although it is strongly marked by the biomedical and technocratic model, there are movements of change in the model of childbirth care, in order to respect women's decisions, defend their rights and encourage to natural and humanized childbirth, thought as a social event and not as a disease. ${ }^{5}$

The speeches of the health professionals play an important part in the formation of the individuals under care. The specialty of obstetric nursing is highlighted, recognized for its competence to act in a humane way in the care of the postpartum woman, participating, above all, in the process of transformation of the practice in the obstetric field, in an attempt to break with the medicalized model, for a less interventionist acting. ${ }^{6-8}$

Thus, it is assumed that the qualified practice of obstetric nurses results, in large part, from self-care and subjectivation processes, regarding decisions about one's own body and life and, consequently, from the power relations that lay down in the care of other women. ${ }^{9}$

Under Foucault's framework, the understanding of the constitution of the individual goes through the understanding of the person as object (processes of objectification): a docile and useful body, through disciplinary practices; and ethically as "subject to" (subjectivation processes), i.e., the individual stuck to his own identity by self-awareness, subject to an identity attributed to him as his own, but also in the sense that works and thinks about himself. ${ }^{10-11}$ Thus the self-care adopted in this study consists of a concept retrieved by Foucault from the Socratic-Platonic philosophical discussions in which an interest is witnessed in the way men self-govern (work and think about themselves). ${ }^{12}$

In this sense, based on the theoretical framework, decisions about life and bodies are understood as expression, materiality of the process of formation of nurses, including processes of objectification and subjectivation, and, therefore, self-care. Thus, it differs from the studies on nurses' power relations usually found in the literature, which focus on references from a liberating perspective, anchored in the conception of active, autonomous and emancipated individuals. ${ }^{9}$

To analyze the power relations involved in the care practices of obstetric nurses, the various dimensions of care were considered: historical, theoretical, philosophical, spiritual, and especially as a social practice. ${ }^{13}$ Thus, we consider the reality of health marked by the need for care(less), for an escape from common and disciplinary practices, in a democratic perspective, adopting care with plurality, a care that ventures to go to the other's domain spaces, which observes and lives the conditions lived by the cared individuals, that is subversion, rather than autonomy and emancipation. In such a way, the political potential of care can be seen, capable of facing gender inequalities (of women) and even in the profession. ${ }^{14}$

Thus, the study aims to analyze the speeches of obstetric nurses on self-care and on decisions about their life and body, as well as the relation with the care intended for other women.

\section{METHOD}

This is a qualitative approach research, anchored in a poststructuralist perspective and in Michel Foucault's theoreticalmethodological framework.

No specific scenario was defined for the investigation, the study being inserted in the field of obstetric nursing, gathering participants inserted in different institutions. The participants were women, obstetric nurses of clear recognition, by those who indicated them, in the care of other women, so that, regarding the body of other women, they have a differentiated performance.

The snowball was chosen as the group definition technique. In this process, the initial participants of the study (convenience sample of initial subjects, called seeds) indicate new participants, who in turn nominate other participants and so on, until the proposed objective is reached. In this type of sampling, the researcher involved in data production seeks to ensure that the chain of indications remains within the relevant limits for the study. ${ }^{15}$

Therefore, to identify the participants, the invitation and interview were made with two obstetric nurses working in Minas Gerais-Brazil, intentionally selected because they have a wide network of contacts, as well as multi-center insertion and extensive experience in the area. They were asked to indicate other obstetric nurses with clear recognition of their role in caring for other women (called daughters of the seeds), seeking to include participants with insertion in different spaces of attention to women and without imposing territorial barriers.

Data was collected through face-to-face interviews with each of the selected participants. The seeds together indicated another 13 Brazilian obstetric nurses, most of whom lived and worked in the Belo Horizonte Metropolitan Region, except for three, one from the Southeast of Minas Gerais and two 
from Curitiba-Paraná. Following the nominations, invitations to attend were sent to all nurses indicated by the seeds and, as they responded and were available, they were interviewed. It is noteworthy that one of the nominations did not respond to the invitation, even after telephone contacts and e-mailing.

The triggering questions of the interview were the following: I would like you to tell me a situation where you had to make a decision about your body and How does this experience affect the care you give to other women? Although the question was formulated singularly, room was allowed for nurses to report more than one situation/experience if they wished. A pre-test was applied in a pilot interview, as directed for research in the area. ${ }^{16}$ The empirical data from this interview were not considered in the analysis and showed that the questions were adequate to the research objectives, requiring only minor changes in structure, which were performed.

All the interviews were conducted by the same researcher, with previous experience in this type of investigation technique. In total there were 14 audio-recorded interviews, from April $15^{\text {th }}$ to September $5^{\text {th }}, 2016$, with an average duration of 32 minutes and totaling seven hours, 33 minutes and 43 seconds of recording.

The interviews were fully transcribed by the researcher who conducted the interviews, concurrently with the collection. The files produced were checked against the audio. Throughout the study, the participants were mentioned with an alphanumeric code formed by EO to symbolize obstetric nurse (enfermeira obstétrica in Portuguese) plus a number (from 1 to 14).

Data analysis was based on a discourse analysis, according to Foucault's conceptual basis. Based on this framework, it is assumed that the analysis includes especially: demarcation of event(s) (from small to large disruptions); apprehension of the discourses of origin, form, organization and function that came to intersect in this event; demonstration of the heterogeneity of the speeches, highlighting the "confrontations" among the speeches; analysis of the formation and game of knowledge in their relations with the institutions and the roles that are prescribed in the speeches. ${ }^{17}$

Operationally, the analysis was initiated by the systematic and thorough reading of the transcribed material, guided by the research question and by the theoretical and methodological directions pointed by Foucault. In the second phase, the reading of the material was redone by marking discourses with different colors, which signaled the following: decision about body and life, processes of objectification (relations of knowledge and power) or processes of subjectivation. After such markings, the description started of the empirical categories that were being constructed and highlighted as the work of capturing and analyzing the discourses took place. Finally, the discussion was carried out, matching the literature adopted in the study. The research findings are organized into two categories: Encounter between the nurse's own body and the body of the woman (women) cared for; and Implications of the encounter for the care practice.

The research project was approved by the Research Ethics Committee of the Federal University of
Minas Gerais on December $9^{\text {th }}, 2015$, under the CAAE opinion - 51373715.0.0000.5149. The research stages are in line with the ethical principles established by the National Health Council (Conselho Nacional de Saúde, CNS), which involve research with human beings according to CNS Resolution No. 466 of December $12^{\text {th }}, 2012$. The participants were informed about the study objectives; its relevance; the free decision to integrate the study, as well as to give up at any stage and the risks offered. By agreeing to participate in the study, the participants signed an agreement through the Free and Informed Consent Form. The right to the confidentiality of the information and anonymity was guaranteed.

\section{RESULTS}

\section{Encounter between the nurse's own body and the body of the woman (women) cared for}

The results indicate that the care provided by the obstetric nurses is permeated by encounters between their own body and the bodies of the women they provide care to. These findings are evidenced by the recurrence of reports of decisions about their own bodies that relate to the professional practice in obstetrics, linked to the birth scenario and to obstetric care: experiences of choice by contraceptive methods; discontinuation of hormone use; deciding when to get pregnant or whether or not to have children. In addition to the participants' discourse, the use of case decisions about their own bodies was used as examples to discuss the assistance provided to women. In this sense, the speeches commonly mix the experience in their own body with the attention given to other women.

The participants reveal that their insertion in the women's health area work was motivated by their experience, in their own bodies or in relation to the bodies of other women, of practices contrary to the recommended by the Humanization Model of Childbirth. Such situations led nurses to a critical thinking about the conformation of women as individuals. At times, these practices were even performed by the nurse herself, but this criticism was only possible after being involved in the process of training in obstetric nursing:

\section{[...] but that's when I found out that I was a female torturer, it was there and then, before I did obstetric nursing I understood that, I took another course, I took a course to assist with delivery and then I saw that the world was spinning differently from that cave that I was inside [...] and then I saw that oops! l'm a female torturer because I do this to these women, I leave them lying here and I don't say anything, I let someone climb over her belly and I don't say anything [...] (EO5).}

In the process of training, preparation and in their own care practice, nurses consider that having experiences faced by the other women under their care is fundamental. This relation is the basis of the principle of empathy, pointed by the participants as important for the practice of all health professionals: 
[...] I think it really interferes with my care for them because, I try to see her differently, because whether or not you put yourself in the other shoes, I think for nursing, for the health professions in general, the issue of empathy, of putting yourself in someone else's shoes is very important (EO7).

So, the fact that my body was violated and my, my emotion, made me become more and more involved in protecting the woman, referring the woman, surrounding the woman and the baby, to the point that they did not suffer the same thing I suffered (EO12).

When their own experiences are satisfactory and considered compatible with the ideologies of the Humanization Model of Childbirth, the obstetric nurse presents the discourse of striving to allow women access to such experiences, without disregarding their life context. Likewise, they report the interest in enabling another woman what cannot be experienced by them, taking this focus as a driver of professional performance:

[...] so, nowadays I understand a lot the woman who feels what I felt. Therefore, I really like to help women with a previous caesarean section to have vaginal delivery, right? [...] so the more difficulty the woman has [laughs] to achieve that, the more I get involved and so it's like I've been giving her what I didn't have, did you get it? (EO10).

But ethically, there was a score by obstetric nurses that, even using their own experiences to assist in the care process of women, they are prudent not to manipulate decisions, understanding that they do not have mastery over the body of others.

The participants emphasize that there is a self-suffering when witnessing violence against the body of the assisted women, because the aggressions also affect the body of this nurse-woman:

It didn't bother me the number of births, but it bothered me a lot the way those women were giving birth. [weeping voice] Wow, very violent, I was thinking my God I want to have a child, but in this way, I don't want to have a vaginal birth [...] (EO1).

The affection in the body of the caregiver nurse is seen by the participants not only in situations of violence, but also when they feel immobilized for not knowing what to do in complex situations. There seems to be a continuous suffering experienced by the participants to feel like a woman, to be aware of her position in the world and of the existence of the reality-producing systems: patriarchalism and capitalism. EO9 calls this process a key-lock mechanism in which women's reality fits perfectly into the life context of the obstetric nurses:
I've seen many obstetric nurses come across emotional situations and then she looks and says, "What do I do with this?" Does not know what to do. Because that got her and so she paralyzed, did you get it? It's actually two paralyzed people, the woman and the nurse. Because that hitched her, why did that make sense to her, right? It's just like the key and the lock. (EO9).

The participants affirm that to be always available to other women, professional commitments are often sovereign to the needs of self-care, physical body care, causing self-neglect and damage to one's own body. But, otherwise, movements in the care of women, especially in the care practice, are emphatically considered pleasurable in the speech of obstetric nurses and, in some cases, are evaluated as the greatest happiness of life. Such satisfaction results from the relation with the bodies of other women and the perception of this woman's achievements. The performance in obstetrics is compared to an addiction that makes nurses dependent on delivery for a living:

[...] I was very happy with many women in childbirth, which is very good, not just good, very good [...] it is very intense that moment, and never comes back, so that for me was also an ecstasy, to see that moment. All for that moment [...] (EO8).

[...] oh, look you get all euphoric [laughs], you see there like this, such a cute childbirth that the woman knows, you know? Won this happy boy from life, right? [...] So, you feel it the same. Wow, I think it's an endorphin anyway, you feel, it's all euphoric. (EO13).

[...] this is very beautiful, think about someone who loves to see it, to see that woman's transformation, from that fear, to turn into struggle and power and she [makes a "jet" noise] goes away [...] (EO9).

\section{Implications of the encounter for the care practice}

In the configuration of the body that takes care of the body of other women, some characteristics of the profile and of the acting as an obstetric nurse are cited as important in the process of fostering qualified practices (respectful and humanized), in particular: understanding women's integrality and the reduction of power asymmetries between professional-patient. Also, being a body available and handed to the woman cared for is an expected action of the obstetric nurse, so that, when asked to indicate another obstetric nurse of clear recognition, those in which the body is available to the other are signaled:

[...] but the active obstetric nurse who believes in the cause, really in the cause [...] You break this nursepatient, doctor-patient relationship, this pseudo power over life, right? We end up seeing a human being in front of us, of course we are still professional, we have our scientific side (EO6). 
Despite pointing out the need to have a different profile for acting in obstetric nursing, the interviewees criticize the current practice in health and the quality of care. They state that during the approach to women, the importance of extrapolating the dimensions of the physical and biological body is not commonly recognized, either because they do not feel responsible, or because of the environment/institution where they were formed:

No, can't understand so if she chose to be a nurse, she has to study anthropology, sociology, she misses this class because nobody, she never read anything about it and she finds it boring [...] Because she never thought politically, she never had a decent high school class where it all wakes up, she never lived in centers like that, so how does she go to college and see that? [...] and do not want to help this woman to get out of it because they think that the problem is not theirs, and in fact the problem is ours (EO6).

The desire to continuously educate, improve, be qualified and specialize is also a factor found in the interviews and linked to the relation with the body of other women, because it is pointed out by the participants as an individual need, but also a means for improving the quality of the care offered. The nurses report that this desire is instigated especially by occurrences in the act of the care practice.

In the professional pathways of care production, the participants narrate difficulties to produce differentiated practices that go beyond the conventional and the biological and create new possibilities for women. In this sense, to allow a womencentered care, to resist the current biomedical model and to protect women from situations of violation experienced, the obstetric nurse finds herself in relationship with other health professionals. These situations are narrated as tense because they involve power relations in which the participants sometimes resist the institutional and medical rules and, in others, submission and permission. Such clashes with philosophies and principles of other professionals are recognized as an important action to ensure progress, but at certain intensities these conflicts can affect the bodies of the women under care:

[...] and today I can breathe "I have to protect this woman; I have to protect the care". And how am I going to react to the other professional who's doing something I don't believe is [...] So, fighting, even an arguing because the other professional was sometimes at the same level of immaturity as me and then it was a mess, we made the care scene worse [...] You have to breathe a lot; you even have to sing [laughs] in order to protect the care scene (EO2).

The clashes with the other professionals in care are pointed out by the participants as causing suffering in their own body. The negative aspects of impact are visualized especially when obstetric nurses realize that the act of being totally available to another woman is exhaustive, with little visibility of results, when another professional interferes in this care and hinders the path that had already been traced by her. But it is noted that, regardless of the wear caused, while the body tolerates it, the obstetric nurse is available to the other woman's body:

[...] our body is so available to women as often as we see ourselves in different positions in childbirth care, you know? So you see yourself sitting on the floor, you find yourself crouching, you find yourself twisting your body so you can follow that woman and do it in that position and after you done all of this then your colleague comes and tells the woman to stay in the position that he wants [...] it frustrates you, you say: "hey... I'm wearing myself, I'm wearing myself' my knee hurts, it hurts, but many times I crouch like this, it hurts usually sitting, walking, but not even because of that I will stop watching this woman, she's comfortable in that position, l'm going to listen to the FHR in that position because I know it works, I can't do one thing that doesn't, but sometimes the other doesn't, "no", so that's pretty frustrating, so your body hurts more, do you know that? (EO5).

\section{DISCUSSION}

The choice to adopt Foucault's framework to investigate the decisions of obstetric nurses about their bodies and life, based on their place, considered the author's analytical perspective on subjectivation. For Foucault, we must abandon a "sacralization" of theories about the individual, adopting another plane of interpretation that considers the individuals in processes located at a given time and place, in subjectivations. ${ }^{18}$

It is noted that bodies and self-care are understood in this study beyond physical and self-care conceptions. The body is constructed as an object of health knowledge, which goes beyond biological and individual aspects, crossed by social, economic, cultural and political dimensions of a given historical period..$^{19-20}$ Moreover, under the post-structuralist framework, the individual is an invention, a discursive production, and an effect of difference, so it is not something external, given and suffering the action of knowledge and power, but the technologies of power create it, individualize and update. ${ }^{21}$

Given these considerations, the results demonstrate the replication of dominant discourses but, above all, the emergence of new discourses. The nursing profession (and the effects of this decision on the bodies) was presented not only as a means of work and support of the participants, but as an important device for training as individuals. In this sense, the self-care, the existence and the transgression of the participants is often related to professional practice.

Each delivery is seen in the narratives as a different emotion that has the potential to transform women and nurses as individuals in the world. It is as if the other woman's body under care consisted of an extension of her own body. Thus, the 
endorphin and oxytocin hormones, active at birth and secreted by the postpartum woman's body, are reminded by obstetric nurses before the feelings of euphoria and dependence felt in their own body. Health work, care-making is "[...] understood not only as an activity, but also as a producer of ways of being, and which constitutes a self, through which the individual recognizes himself/herself". $22: 98$

The raw material of nursing work is primarily the encounter between individuals. ${ }^{23}$ Thus, in a philosophical and spiritual perspective of nursing care, by putting yourself in the other's shoes, bringing their experiences closer to those of women, reporting suffering and also satisfaction experienced by the care provided and striving to be in constant formation, there seems to be more than empathy in the speech of obstetric nurses mentioned by them in the interviews, an approximation with the attributes of compassion. It is important to point out this recurrent finding in the analysis, as nurses are indicated by the clear recognition in their performance.

Compassion is an ancient philosophical concept, with varying definitions, but it falls short of objective understanding since it is a complex phenomenon, closely related to the human condition and, consequently, to nursing and care. ${ }^{24}$ In turn, what goes beyond the individual, the conception of care, of charity, compassion and generosity and as a theory of care, is pointed out as necessary for the comprehensiveness of the human being in its complexity. ${ }^{25}$

Still considering the empirical data, especially the consideration of comprehensiveness as a good guide for the quality of care and speeches that mark a concern with the social position occupied by women in society, there is also the potential of democratic obstetric care and politicians, drivers of critical individuals, as a practice that allows new possibilities of the existence of the being cared for and of the caregiver. ${ }^{14}$

However, taking a critical look at the speeches, it is pointed out that, although there is a consideration of the obstetric nurses precaution so as not to influence too much on the women's behavior, the participants concern about having lived similar situations of those women, as well as allowing or denying certain experiences, leads one to believe that the discursive practices tend to produce gestures and truths in women, but one must be careful to identify ways to avoid the effects of domination. ${ }^{26}$

The indication by the participants of an ideal obstetric nurse profile may be related to their interest in identities, even the identity of an obstetric nurse. But in the face of Foucault's warning that "[...] power exercises direct ascendancy over individuals by concentrating on the constitution of identities through the imposition of places, time and even gestures."27:146-7, it is necessary to consider that the identification of the nurse with this profile can massify singular practices and not guarantee the production of qualified care.

Based on the understanding of power as a producer/ transformer vector and a bottom-up analysis, daily, microstructural changes in social relations are valued and not necessarily included in health policies. ${ }^{28}$ Thus, in such a way that any and every social place can be the scene of resistance, based on different strategies, it is in counterpart to biopower which (re)produces not only commodities but also subjectivities and consciences - which is called by some authors like plural biopower of the crowd, manifested in social cooperation, affective and political union, subversion and escape, protest and creation, a shared desire..$^{29-30}$

Thus, the collective narrative presented is marked by the attitude of compassion, the subjectivation processes incited by the professional practice, indicative of a potential for critical and political care and the construction of a network of interweaving among obstetric nurses, recognized for the clarity of their contributions for the care of women. Given this, the biopower present in the collectives is highlighted, marked by the intersection of stories and practices, to change the model of women care. This collective potential that exists in obstetric nursing can be observed since the relatively recent creation (1992) of the Brazilian Association of Midwives and Obstetric Nurses (Associação Brasileira de Obstetrizes e Enfermeiros Obstetras, ABENFO-National), which was born of a political alliance between midwives and obstetric nurses that already extends in 26 sectionals in the Brazilian states. ${ }^{6}$

\section{CONCLUSIONS AND IMPLICATIONS FOR PRACTICE}

It is noted that the reality of health is permeated by the great precariousness of professionals, which usually weakens themselves and the users. Thus, it is not enough to study the proposal of women care production from them and their instituted ones, but to study how the proposal is lived in daily life, from its impasses and how the professional (re)positions (or not) from what is demanded from her, how it is built each time, with the team, with the women she serves, how does the encounter that promotes effective care occur.

Given the results and discussion presented, in relation to the processes of objectification, it seems from the collective and from the political subjectivation, that obstetric nurses, who mention the care model so much, will be able to (re)set and transcend it. But singular subjectivation processes seem to be fundamental for transgression as women, nurses, and caregivers of other women, and acting in obstetric nursing results in producing effects of self-care and care(less) of other women.

Each study has its peculiarities, especially regarding a qualitative research guided by a post-structuralist referential, but the methodological approach conducted serves as an example or inspiration for research that seeks to analyze the uniqueness of nurses, understanding that the nursing work is part of a construction of life as formed individuals and discourse makers.

Regarding the limitations of the study, it is necessary to consider that the narratives of the participants in their entirety were true works of existence and presenting them in their singularities and in the work of each individual could cause 
situations of exposure and identification of the participants. Therefore, it was decided to work with transversality, of course, allowing space for discourses of difference.

The present study contributes substantially to the analysis and knowledge of the life and care scenario of obstetric nurses, demonstrating the innovation potential of this qualitative production that starts from the subjectivation for a discussion of care provided to women. The choice of the research method, besides producing self-reflection of the participants involved, allowed us to analyze the self-encounter with the other woman, reaffirming the potential of the art of care present in the practices of these women and obstetric nurses. In this sense lies its ethical and political merit: pointing out what from oneself influences in the professional practice, taking the production of individuals and subjectivities as its starting point.

Operationally, some methodological choices relevant to the achievement of the results stand out: to include participants of clear recognition, besides the option for the snowball method and the open in-depth interview. These choices allowed the empirical data to flow, having content for deep discussion.

The constructed analytics is partial, unfinished, not absolute truth and does not seek to confer linearity, just a nomadic experience, just as nursing should be. Thus, due to its characteristic of data production and permissiveness of multiple approaches, it was possible to identify other necessary and possible deepening points for further research.

\section{ACKNWOLEDGMENTS}

We thank each obstetric nurse who participated in the research, trusting their life story.

\section{REFERENCES}

1. Del Priore M. Histórias e conversas de mulher: amor, sexo, casamento e trabalho em mais de 200 anos de história. São Paulo: Planeta; 2014

2. Ministério da Saúde (BR). Conselho Nacional de Saúde (CNS). Documento orientador: $2^{a}$ Conferência Nacional de Saúde das Mulheres. Saúde das Mulheres: desafios para integralidade com equidade [Internet]. Brasília (DF): Ministério da Saúde;2017 [cited 2017 Dec 21]. Available from: http://conselho.saude.gov.br/ultimas_noticias/2016/11nov23_ pagina_inicial_converencia_saude_mulher.html

3. Mello L, Gonçalves E. Diferença e interseccionalidade: notas para pensar práticas em saúde. Rev Cronos [Internet]. 2010; [cited 2019 Feb 04]; 11(2):163-73. Available from: https://periodicos.ufrn.br/cronos/ article/view/2157

4. Leal MC, Pereira APE, Domingues RMSM, Theme Filha MM, Dias MAB, Nakamura-Pereira M, et al. Obstetric interventions during labor and childbirth in Brazilian low-risk women. Cad Saúde Pública [Internet]. 2014; [cited 2017 Dec 21]; 30(Supl. 1):S17-32. Available from: http:// www.scielo.br/scielo.php?script=sci_arttext\&pid=S0102-311X2014001 300005\&lng=pt\&nrm=iso\&tlng=en. DOI: http://dx.doi.org/10.1590/0102$-311 \times 00151513$

5. Andrade MAC, Lima JBMC. O Modelo Obstétrico e Neonatal que Defendemos e com o qual Trabalhamos. In: Brasil. Ministério da Saúde. Universidade Estadual do Ceará. Cadernos Humaniza SUS: Volume 4. Humanização do Parto e Nascimento. Brasília (DF): Ministério da Saúde; 2014. p. 19-46.
6. Mouta RJO, Progianti JM. Process of creating the Brazilian Association of Midwives and Obstetric Nurses. Texto Contexto Enferm [Internet]. 2017 Feb; [cited 2018 Jan 6];26(1):e5210015. Available from: http://www.scielo.br/scielo.php?script=sci_arttext\&pid=S0104-07072017000100306 DOI: http://dx.doi.org/10.1590/0104-07072017005210015

7. Moura FMJSP, Crizostomo CD, Nery IS, Mendonça RCM, Araújo OD Rocha SS. Humanization and nursing assistance to normal childbirth. Rev Bras Enferm [Internet]. 2007 Jul/Aug; [cited 2017 Dec 21]; 60(4):4525. Available from: http://www.scielo.br/scielo.php?script=sci_arttext\&p d=S0034-71672007000400018. DOI: http://dx.doi.org/10.1590/S003471672007000400018

8. Vargens OMC, Silva ACV, Progianti JM. The contribution of nurse midwives to consolidating humanized childbirth in maternity hospitals in Rio de Janeiro-Brazil. Esc Anna Nery [Internet]. 2017 Feb; [cited 2017 Dec 21]; 21(1):e20170015. Available from: http://www.scielo.br/scielo. php?pid=S1414-81452017000100215\&script=sci_arttext\&tlng=en DOI: http://dx.doi.org/10.5935/1414-8145.20170015

9. Rabelo ARM, Silva KL. Care of the self and power relations: female nurses taking care of other women. Rev Bras Enferm [Internet] 2016 Nov/Dec; [cited 2017 Dec 21]; 69(6):1204-14. Available from http://www.scielo.br/scielo.php?script=sci_arttext\&pid=S0034 $-71672016000601204 \& \operatorname{lng}=e n \& n r m=i s o \& t \operatorname{lng}=e n$. DOI: http://dx.doi. org/10.1590/0034-7167-2016-0021

10. Fonseca MA. A preocupação com o sujeito e o poder. In: Fonseca MA, ed. Michel Foucault e a constituição do sujeito. São Paulo: Educ; 1995 p. 21-37.

11. Veiga-Neto A. Temas foucaultianos: o sujeito. In: Veiga-Neto A, ed Foucault e a educação. Belo Horizonte (MG): Autêntica; 2003. p. 131-40.

12. Gondra J, Kohan W. Foucault 80 anos. Belo Horizonte (MG): Autêntica; 2006. p. 45-56.

13. Salviano MEM, Nascimento PDFS, Paula MA, Vieira CS, Frison SS, Maia MA, et al. Epistemology of nursing care: a reflection on its foundations. Rev Bras Enferm [Internet]. 2016 Nov/Dec; [cited 2019 Jul 20]; 69(6):1240-5. Available from: http://www.scielo.br/scielo. php? pid=S0034-71672016000601240\&script=sci_arttext\&tIng=en DOI: http://dx.doi.org/10.1590/0034-7167-2016-0331

14. Pires MRGM, Fonseca RMGS, Padilha B. Politicy of care in the criticism towards gender stereotypes. Rev Bras Enferm [Internet]. 2016 Nov/Dec [cited $2018 \mathrm{Jul}$ 31]; 69(6):1156-62. Available from: http://www.scielo. br/pdf/reben/v69n6/en_0034-7167-reben-69-06-1223.pdf. DOI: http:// dx.doi.org/10.1590/0034-7167-2016-0441

15. Etikan I, Alkassim R, Abubakar S. Comparision of Snowball Sampling and Sequential Sampling Technique. Biom Biostat Int J [Internet]. 2016 [cited 2019 Feb 4]; 1(3):6-7. Available from: http://medcraveonline.com/ BBIJ/BBIJ-03-00055.pdf. DOI: 10.15406/bbij.2015.03.00055

16. Paula CC, Padoin SMM, Terra MG, Souza IEO, Cabral IE. Modos de condução da entrevista em pesquisa fenomenológica: relato de experiência. Rev Bras Enferm [Internet]. 2014 May/Jun; [cited 2017 Dec 21]; 67(3):468-72. Available from: http://www.scielo.br/pdf/ reben/v67n3/0034-7167-reben-67-03-0468.pdf. DOI: http://dx.doi. org/10.5935/0034-7167.20140063

17. Foucault M. Eu, Pierre Rivière, que degolei minha mãe, minha irmã e meu irmão: um caso de parricídio do século XIX, apresentado por Miche Foucault. Rio de Janeiro: Edições Graal; 1991.

18. Ferreira Neto JL. The Analytic of Subjectivation in Michel Foucault. Rev Polis Psique [Internet]. 2017; [cited 2019 Feb 4]; 7(3):7-25. Available from: https://seer.ufrgs.br/PolisePsique/article/view/76339.DOI: https:// doi.org/10.22456/2238-152X.76339

19. Carvalho SR, Gastaldo D. Promoção à saúde e empoderamento: uma reflexão a partir das perspectivas crítico-social pós-estruturalista. Ciênc Saúde Coletiva [Internet]. 2008 Dec; [cited 2017 Dec 23] 13(Suppl.2):2029-40. Available from: http://www.scielo.br/scielo. php?script=sci_arttext $\&$ pid=S1413-81232008000900007

20. Gastaldo D. Is health education good for you? Rethinking health education through the concept of bio-power. In: Petersen A, Bunton R, orgs. Foucault, health and medicine. London: Routledge; 1997. p. 113-32. 
21. Carneiro RG. Cenas de parto e políticas do corpo. Rio de Janeiro: Fiocruz; 2015.

22. Lucena MAG. As práticas de si e o cuidado de si no fazer profissional de saúde: uma leitura a partir de Michel Foucault [dissertação]. Caxias do Sul: Universidade de Caxias do Sul [Internet]. 2014; [cited 2019 Sep 13]. Available from: https://repositorio.ucs.br/xmlui/bitstream/ handle/11338/858/Dissertacao\%20Maria\%20Angelica\%20Gazzana\%20de\%20Lucena.pdf?sequence $=1$ \&isAllowed $=y$

23. Ayres JRCM. Care: work, interaction and knowing health practices. Rev Baiana Enferm [Internet]. 2018; [cited 2018 Jul 31]; 31(1):e21847. Available from: https://portalseer.ufba.br/index.php/enfermagem/ article/view/21847/14172. DOI: http://dx.doi.org/10.18471/rbe. v31i1.21847

24. Reis AMS. A compaixão entre enfermeiros em saúde infantil e pediatria: análise do conceito [dissertação]. Porto: Escola Superior de Enfermagem do Porto [Internet]. 2014; [cited 2018 Jul 28]. Available from: https://comum.rcaap.pt/bitstream/10400.26/9491/1/ Disserta\%C3\%A7\%C3\%A30\%20Enf\%C2\%AA\%20Ana\%20Reis.pdf
25. Nunes ECDA, Silva LWS, Oliveira JM, Oliveira PCM. Refletindo o 'Transpessoal' humano - uma compreensão multidisciplinar em transversalidade com o estado da arte de ser. Rev Enferm Refer [Internet]. 2010; [cited 2018 Jul 31]; 2:173-80. Available from: http:// www.scielo.mec.pt/scielo.php?script=sci_arttext\&pid=S0874$-02832010000400018 \&$ lng=pt\&nrm=iso. ISSN 0874-0283.

26. Foucault M. A ética do Cuidado de Si como Prática da Liberdade. In Foucault M, ed. Ditos e Escritos V: Etica, sexualidade, política. Rio de Janeiro: Forense; 2004. p. 264-87.

27. Bert JF. Práticas de si e relação com o outro. In: Bert JF, ed. Pensar com Michel Foucault. Cap IV. São Paulo: Parábola; 2013. p. 145-68.

28. Souza WL. Ensaio sobre a noção de poder em Michel Foucault. Rev Múlt Leit [Internet]. 2011; [cited 2017 Dec 21]; 4(2):103-24. Available from: file:///C:/Users/susana/Downloads/3160-8427-1-PB.pdf

29. Duarte AM. Vidas em Risco: Crítica do presente em Heidegger, Arendt e Foucault. Rio de Janeiro: Forense Universitária; 2010.

30. Furlin N. Sujeito e agência no pensamento de Judith Butler: contribuições para a teoria social. Soc Cult [Internet]. $2013 \mathrm{Jul} / \mathrm{Dec}$; [cited 2017 Dec 21]; 16(2):395-403. Available from: https://revistas.ufg.br/ fchf/article/view/32198 